\title{
Correction to: Globalized inexact proximal Newton-type methods for nonconvex composite functions
}

\author{
Christian Kanzow $^{1}$ (D) Theresa Lechner $^{1}$
}

Published online: 21 July 2021

(c) The Author(s) 2021

\section{Correction to: Computational Optimization and Applications (2021) 78: 377-410 https://doi.org/10.1007/s10589-020-00243-6}

The article "Globalized inexact proximal Newton-type methods for nonconvex composite functions", written by Christian Kanzow and Theresa Lechner, was originally published electronically on the publisher's internet portal on 16 November 2020 without open access. With the author(s)' decision to opt for Open Choice the copyright of the article changed on 7 July 2021 to $\odot$ The Author(s) 2020 and the article is forthwith distributed under a Creative Commons Attribution 4.0 International License, which permits use, sharing, adaptation, distribution and reproduction in any medium or format, as long as you give appropriate credit to the original author(s) and the source, provide a link to the Creative Commons licence, and indicate if changes were made. The images or other third party material in this article are included in the article's Creative Commons licence, unless indicated otherwise in a credit line to the material. If material is not included in the article's Creative Commons licence and your intended use is not permitted by statutory regulation or exceeds the permitted use, you will need to obtain permission directly from the copyright holder. To view a copy of this licence, visit http://creativecommons.org/licen ses/by/4.0.

Open Access This article is licensed under a Creative Commons Attribution 4.0 International License, which permits use, sharing, adaptation, distribution and reproduction in any medium or format, as long

The original article can be found online at https://doi.org/10.1007/s10589-020-00243-6.

Christian Kanzow

kanzow@mathematik.uni-wuerzburg.de

Theresa Lechner

theresa.lechner2@mathematik.uni-wuerzburg.de

1 University of Würzburg, Institute of Mathematics, Emil-Fischer-Str. 30, 97074 Würzburg, Germany 
as you give appropriate credit to the original author(s) and the source, provide a link to the Creative Commons licence, and indicate if changes were made. The images or other third party material in this article are included in the article's Creative Commons licence, unless indicated otherwise in a credit line to the material. If material is not included in the article's Creative Commons licence and your intended use is not permitted by statutory regulation or exceeds the permitted use, you will need to obtain permission directly from the copyright holder. To view a copy of this licence, visit http://creativecommons.org/ licenses/by/4.0/.

Publisher's Note Springer Nature remains neutral with regard to jurisdictional claims in published maps and institutional affiliations. 